\begin{tabular}{|c|c|c|}
\hline Beitr. Ent. & Keltern & ISSN 0005-805X \\
\hline $\mathbf{5 7}(2007) 1$ & S. $135-150$ & 30.06 .2007 \\
\hline
\end{tabular}

\title{
Revision of Stauronematus BENSON, 1953 and additions to the sawfly fauna of Corsica and Sardinia
}

\author{
(Hymenoptera, Tenthredinidae)
}

With 17 figures

ANDREw D. Liston

\begin{abstract}
Summary
Cladius pallipes Serville, 1823 is a new synonym of Tenthredo compressicornis Fabricius, 1804. The valid name of the species formerly known as Stauronematus compressicornis (F.) is Stauronematus platycerus (Hartig, 1840) comb. nov. Valid name of Cladius (Priophorus) pallipes Serville is Cladius (Priophorus) compressicornis (F.) comb. nov. Type species of Stauronema Benson, 1948 (preoccupied) and its replacement name Stauronematus Benson, 1953 is here fixed as Nematus platycerus Hartig, 1840. Stauronematus saliciphilus sp. n. is described from Corsica and Sardinia. Hostplant is Salix atrocinerea. Stauronematus saliciphilus is compared with its only other known congener S. platycerus, larval hosts Populus spp. Lectotypes are designated for Tenthredo compressicornis, Nematus platycerus and Nematus callicerus Thomson, 1863. Previous statements that Stauronematus Benson, 1953 has a Holarctic distribution are mistaken. At present, definite records are only from the Palaearctic. Three species of Tenthredinidae are recorded for the first time in Corsica and six in Sardinia. The important role of Salix species for the diversity of the sawfly fauna of Corsica and Sardinia is highlighted.
\end{abstract}

\section{Zusammenfassung}

Cladius pallipes Serville, 1823 ist ein neues Synonym von Tenthredo compressicornis Fabricius, 1804. Der gültige Name für die Art, die bisher als Stauronematus compressicornis (F.) bekannt war, ist Stauronematus platycerus (Hartig, 1840) comb. nov. Der gültige Name von Cladius (Priophorus) pallipes Serville ist Cladius (Priophorus) compressicornis (F.) comb. nov. Als Gattungstypus von Stauronema Benson, 1948 (präokkupiert) und ihr Ersatzname Stauronematus Benson, 1953 wird hier Nematus platycerus Hartig, 1840 festgelegt. Stauronematus saliciphilus sp. n. (Wirtspflanze Salix atrocinerea) wird als zweite Art der Gattung von Korsika und Sardinien beschrieben und mit S. platycerus (Wirtspflanzen Populus-Arten) verglichen. Lectotypen werden für Tenthredo compressicornis Fabricius, Nematus platycerus HaRTig und Nematus callicerus Thomson, 1863 designiert. Entgegen Literaturangaben, ist Stauronematus nicht holarktisch verbreitet. Drei Tenthredinidae-Arten werden erstmalig für Korsika nachgewiesen. Sechs sind neu für Sardinien. Die wichtige Rolle, welche Salix-Arten für die Diversität der Blattwespenfauna in Korsika und Sardinien spielen, wird unterstrichen.

\section{Keywords}

Taxonomy, distribution, Stauronematus, Cladius, Corsica, Sardinia, Salix. 


\section{Introduction}

Following field excursions in Corsica in 2004 (Liston \& SрÄTH 2005), this island was visited once more by Dr. J. SрÄтH in April 2005 with the specific objective of collecting sawflies. A few species not previously found there were detected. The author collected in Sardinia in April 2006. Although only 15 sawfly species were found, 6 of these are additions to the known fauna of Sardinia. This contribution presents data mainly on species new to the fauna of these islands, including some older material in the collection of the Deutsches Entomologisches Institut, Müncheberg. The genus Stauronematus BENSON, 1953 is revised, in connection with a previously undescribed species found in Corsica and Sardinia, and brief comments on other species of particular interest presented.

\section{Material and methods}

Material in the following collections was examined:

$\begin{array}{ll}\text { ZMUC } & \text { Zoological Museum, University of Copenhagen, Denmark } \\ \text { DEI } & \text { Deutsches Entomologisches Institut, Müncheberg, Germany } \\ \text { JLC } & \text { Private collection of JeAn LACOURT, Igé, France } \\ \text { JSC } & \text { Private collection of Jochen SpäTH, Dingolfing, Germany } \\ \text { RMNH } & \text { Nationaal Natuurhistorisch Museum, Leiden, Netherlands } \\ \text { MZLU } & \text { Zoological Museum, University of Lund, Sweden } \\ \text { ZSM } & \text { Zoologische Staatssammlung, Munich, Germany }\end{array}$

Label data of type specimens is given verbatim, but for other specimens is translated where necessary into English.

\section{Revision of the genus Stauronematus BENson, 1953 (Nematinae)}

Stauronema Benson, 1948: 22. Type species by original designation Tenthredo compressicornis Fabricius, 1804. Monotypic. Preoccupied by Stauronema Sollas, 1877 (Porifera).

Stauronematus Benson, 1953: 153. New name for Stauronema.

Under article 70.3.2 (ICZN 1999) the type species of Stauronema Benson, 1948 and its replacement name Stauronematus Benson, 1953 is now fixed as Nematus platycerus HarTig, 1840, misidentified by BENSON (1948) in the original designation as Tenthredo compressicornis FABRICIUS, 1804 (see below).

\section{Description}

Mouth-parts normal; maxillary palp longer than cardo with stipes, and articles 3 and 5 the longest. Labial palps about twice as long as ligula. Clypeus subtruncate in front, very narrow. Malar space only about half as long as distance between antennal sockets. Inter-antennal crest very prominent, medially carinate. Antenna in female subcylindrical and about as long as costa and stigma of forewing; in male laterally compressed (so that third segment is scarcely four times longer than broad) with each segment produced at the apex beneath, as long as body with head. Wing venation as in Pristiphora Latreille, 1810: costa strongly swollen at the apex so that at the point of origin of cubital vein from subcosta the intercostal area is only about as wide as medial width of costa, radial cell without cross-vein, intercostal vein received on the subcosta before the origin of cubital, 
and anal cell without basal loop. Claws with swollen basal lobe and an inner tooth, well separated from end tooth and longer than it. Sawsheath rounded behind in dorsal aspect, (Fig. 1), basally constricted; male with procidentia of eighth tergite not extending beyond slightly excised apex of segment, reaching maximally one half of the length of the tergite, triangular in form, medially elevated but not clearly carinate, delimited by two obtusely angled furrows converging forwards. Penisvalve (Fig. 2): valvispina long and straight, arising from dorsal margin of paravalva.

\section{Diagnosis}

Adult morphology resembles Pristiphora Latreille, 1810. Stauronematus can be recognised by the combination of long inner tooth and presence of a basal lobe on the tarsal claws, and the form of the sawsheath: in dorsal view basally constricted, apically tapering, subtriangular. Claws of Pristiphora simple or with a small basal tooth, rarely bifid and never with a basal lobe. In most Pristiphora species sawsheath is apically subtruncate or excised on either side of the middle, often with a pronounced scopa, and not basally constricted. The complex shape of the serrulae of the lancet of Stauronematus does not occur in any species of Pristiphora. Penisvalve of Stauronematus with valvispina long and straight, arising dorsally of ventral margin of paravalva. In Pristiphora the valvispina short or long, often curved strongly upwards: where long, it arises from the ventral margin of paravalva. Larva of Stauronematus with 3rd abdominal segment bearing setae on annulets 1, 2 and 4. Pristiphora has setae only on annulets 2 and 4.

\section{Remarks}

Stauronematus has generally been accepted as a valid genus, its monophyly being supported by several morphological characters of adults and larvae (Wong 1969, Lorenz \& Kraus 1957) and a unique feature of larval behaviour, i.e. the "palisade" of dried secretion surrounding the feeding place, first described by Vollenhoven (1858). Lacourt (1998) went as far as to propose a new monotypic tribe, Stauronematini, for the genus. Alternatively, some authors have treated it as a subgenus of Pristiphora (e. g. GOULET 1992), whose adults are in many respects morphologically similar. Until the phylogeny of the Nematinae has been better studied, its sister group remains uncertain.

The single existing syntype of Tenthredo compressicornis FABRICIUs was examined, with the following result:

\section{Cladius (Priophorus) compressicornis (FABRICIUS, 1804) new combination}

Tenthredo compressicornis FABricius, 1804: 38-39, No. 46, [^], type locality: Dania [Denmark]. Cladius pallipes Serville, 1823: 78, no. 5, o o $\sigma^{\star}$, type locality: France, Paris. Lectotype designated by Blank \& TAEger (1998: 166). syn. nov.

Cladius pallipes Lepeletier, 1823: 59, no. 169, 우 ơ , type locality: France, environs of Paris. syn. nov.

Priophorus pallipes (Lepeletier, 1823): Benson 1958; 143.

Priophorus pallipes (Serville, 1823): Blank \& Taeger 1998; 166.

Further synonyms of this species are listed by SMITH (1979: 50) under Priophorus pallipes (LEPELETIER, 1823).

Material (Figs 4, 5):

Tenthredo compressicornis. Lectotype, (here designated) ơ : [red label, printed] "TYPE", [handwritten] "Sjellandia [Island of Sjaelland, Denmark] Mus. T. Lund, Tenthredo compressicornis Fab.", "Cladius (Priophorus) compressicornis (F.) det. LisTON 2006" "LECTOTYPE: Tenthredo compres- 
sicornis FABricius, 1804, des. Liston 2006", ZMUC. Condition: missing are entire abdomen, rear legs apart from coxae, right forewing, antennomere 9 of left antenna. The second label was evidently not written by Fabricius (cf. handwriting samples in Horn et al. 1990). It can no longer be ascertained whether FABRICIUS based his description on one or more specimens. ZIMSEN (1964) records the existence of only one syntype specimen, in the Copenhagen collection.

\section{The original description of Tenthredo compressicornis reads:}

"T.[Tenthredo] filiformibus compressis pubescentibus nigra pedibus rufis. Habitat in Dania Mus. Dom. Lund. Statura omnino praecedentium [T. fulvicornis]. Antennae fere longitudine corporis, compressae, subpilosae, nigrae. Caput, thorax, abdomen nigra, immaculata. Alae albae. Pedes rufi.". Tenthredo fulvicornis PANzer sensu FABRICIUS is usually regarded as a misidentification of Hoplocampa minuta (CHrist, 1791). Klug (1819) gives the body length of a male specimen under this name in the FABRICIUS Collection as "2 Linien", which equates to approximately $4 \mathrm{~mm}$. However, some larger males of $H$. minuta in the DEI collection are $5 \mathrm{~mm}$ long. Typical male specimens of Cladius compressicornis are not less than $5 \mathrm{~mm}$ long, but the original length of the lectotype is not clear, because the abdomen is missing. In all other respects, the lectotype agrees with FABRICIUS's description. Although the sex of the specimen(s) which he described as T. compressicornis is not explicitly mentioned, the very long, compressed antennae are found in European Nematinae only in the males of a few species. Those of females of the same species are shorter and subcylindrical. The description does almost also fit the male of Stauronematus platycerus (HARTIG, 1840), except that the tegulae are invariably conspicuously pale in the latter, a character which FABRICIUS would surely not have overlooked.

Note that Dusmet (1949: 457) used the name compressicornis Fabricius in combination with Cladius while referring to a male specimen. He gives no explanation for this usage. It seems unlikely that he examined Fabricius's material. Possibly he was led to place S. platycerus in Cladius because of the form of its antennae, but in the same paper (p. 459) he refers separately to Lygaeonematus compressicornis (F.), so that the first name combination might also be considered the result of a mistake.

\section{Species identification of Stauronematus}

A. Pronotum completely black, or only extreme upper and rear edges brown (Figs 6, 7). Female head in dorsal view subparallel behind eyes, male only slightly contracted (Figs 6, 7). Abdomen entirely black. Mesepisternum more densely pubescent above than below but usually without entirely glabrous area on lower half (Fig. 3). Rear coxa with at least basal half black. Wing membrane hyaline. Lancet with 19 annulets (Fig. 8). Penisvalve with ventral margin of paravalva not emarginate (Fig. 2). Body length 5.0-6.5 mm. Larval hosts: Populus spp. Records from Salix require confirmation ..Stauronematus platycerus (HarTig, 1840)

B. Pronotum almost completely pale white or bright yellow, only ventral margins black (Figs 9, 10). Head in dorsal view sharply contracted behind eyes (Figs 9, 10). Female abdomen with at least hypopygial area pale brown, sometimes abdomen medially completely pale (yellow) (Figs 11, 12). Male with subgenital plate and harpes brown. Mesepisternum usually with a sharply defined entirely glabrous area on lower half. Rear coxa with only extreme base black. Wing membrane slightly infuscate. Lancet with 16 annulets (Fig. 13). Penisvalve with ventral margin of paravalva emarginate (Figs 14, 15). Body length $5.0-5.5 \mathrm{~mm}$. Larval host: Salix atrocinerea. S. purpurea requires confirmation .... Stauronematus saliciphilus new species 


\section{Stauronematus platycerus (HARTIG, 1840) sp. rev., comb. nov.}

Nematus platycerus HaRTiG, 1840: 27, ơ , type locality: North Germany [according to introduction]. The name platycerus is to be treated as a noun. Synonymised by Cameron (1885: 55) with Nematus compressicornis auct.

Nematus vallator Vollenhoven, 1858: 191-194, o o larva, hostplant Populus nigra var. italica, type locality: Den Haag, Netherlands. Synonymised by Cameron (1878: 267) with Nematus compressicornis auct. Lectotype designated by Thомаs (1987).

Nematus callicerus Thomson, 1863: 619-620, ㅇ, type locality: Ringsjön, Scania, Sweden. Synonymised by Cameron (1885: 55) with Nematus compressicornis auct.

?Nematus cebrionicornis A. Costa, 1859: 20, ơ , type locality: Camaldoli Hills, near Naples, Italy. Synonymised by CAMERON (1885: 55) with Nematus compressicornis auct.

Nematus compressicornis: misidentification by CAMERON (1878: 267).

Lygaeonematus compressicornis: Konow (1890: 247).

Stauronema compressicornis: BENSON (1948: 22).

Stauronematus compressicornis: Benson (1953: 153).

Pristiphora compressicornis: Muche (1974: 62).

Pristiphora (Stauronematus) compressicornis: Muche (1977: 313).

Nematus (Stauronematus) compressicornis: ZHeLOCHOvTSEV (1988: 144).

Lygaeonematus platyceros (HARTIG): Konow (1890: 247), misspelling.

\section{Type material examined}

Nematus platycerus Hartig. Lectotype (here designated) ơ : [red, printed] "Cotype", "Nematus platycerus HtG, Th. Hartig det.", "Lygaeonematus compressicornis F. o, E. Clémont det.", "platycerus m.", [printed] "Sammlung Th Hartig", "Lectotype Nematus platycerus Hartig, 1840 designated Liston 2006", "GBIF-GISHym 3385", ZSM. Condition: missing are right posterior leg apart from coxa and trochanter, tarsus of left posterior leg.

Nematus vallator Vollenhoven. Lectotype (designated by Thomas 1987) \& : [red] "Museum Leiden, Syntype, Nematus vallator Vollenhoven 1858", [green, round] "v. Voll. Leyd. 6", "Lygaeonematus vallator v. Voll. Det.", "Lygaeonematus compressicornis FR. ㅇ ", "Stauronematus compressicornis (FABR.), o det. P. Thomas XII. 1985", "Lectotype P. Thomas 1986", RMNH. Condition: good, but partly faded body colour (black has become brown).

Nematus callicerus Thomson. Lectotype (here designated) + : small square label with green upperside, "Lectotype Nematus callicerus Thomson, 1863 designated Liston 2006", "Stauronematus platycerus (HarTig, 1840) + det. Liston 2006", MZLU. Good condition. All specimens under the name Nematus callicerus in the THOMson collection were examined. Only the second specimen in the series can be regarded as a syntype. The small green label indicates that this was collected at the type locality Ringsjön (R. DANIELsson, pers. comm.). A second male specimen with a similar green label can not be regarded as a syntype, because Thомson only described the female sex.

Nematus cebrionicornis Costa was not available for examination. CAMEron's synonymy of this taxon with Nematus compressicornis seems justified. The description of the thorax as completely black except for the pale tegulae corresponds with $S$. platycerus, but not with $S$. saliciphilus sp. n. GHigr (1905) in a revision of material including Costa's types held by the Naples Museum, did not mention cebrionicornis by name, but lists a male or males which he identified as Lygaeonematus compressicornis (F.) from Camaldoli (the type locality for N. cebrionicornis as given by Costa).

Diagnostic combination (see also key, above):

Most valuable single external character for separating $S$. platycerus from S. saliciphilus, in both sexes, is the colour of the pronotum. This is black in platycerus, at most edged with a dull brown 
tint, and clear white or yellow in saliciphilus. Shape of the head behind the eyes, although slightly variable in both species, is much more sharply contracted in the female of saliciphilus. This difference is not so pronounced in the males. The entirely glabrous patch on the lower part of the mesepisternum typical of saliciphilus is not completely constant: one female from Sardinia has no such patch. Conversely, $S$. platycerus normally has the mesepisternum entirely pubescent although two female specimens of a total of 47 examined possess a non-pubescent area. The slightly darker wing membrane of saliciphilus appears to be a constant character, but is difficult to appreciate unless specimens can be compared directly.

The gross morphology of the lamnium of the female lancet appears to be constant in both species (3 specimens of saliciphilus and 9 platycerus examined). Stauronematus saliciphilus has 16 serrulae, S. platycerus 19. The reduced number in S. saliciphilus is compensated by an increase in their size, so that the length of the spaces between the serrulae relative to the length of a serrula is similar in both species. The penisvalve of $S$. saliciphilus is very similar to that of $S$. platycerus. Further males of saliciphilus will have to be obtained in order to reveal whether the apparent difference in the outline of the ventral edge of the paravalva is a useful character for distinction of the species.

\section{Variability:}

In all German specimens examined, the pronotum is completely black. Benson (1958) and Zhelochovtsev (1988) state that the corners of pronotum are yellow. Muche (1974) noted this discrepancy, stating that in the material which he had seen, the pronotum is all black. According to Cameron (1885: 48, key) the pronotum is entirely black. About half of the specimens examined from Sweden and the Netherlands have brown upper and rear edges of the pronotum, in the others the pronotum is completely black. V. VIKBERG (pers. comm.) noticed a similar testaceous colouration in all of ten specimens reared in Helsinki from Populus tremula and one captured male and female from Slovakia. The mesepisternum is usually slightly pubescent on lower half, rarely with glabrous patch. Rear femur usually entirely pale, occasionally with a dorso-apical black spot. The labrum may be black or brownish.

Distribution: Apparently widespread in the Palaearctic (TAeger et al. 2006; Verzhutski 1981; XIAO et al. 1992). Material from the following countries has been examined: Norway, Sweden, the Netherlands, Germany, France, Turkey and China.

Hostplant: Oligophagous on various species of Populus. Sometimes a severe pest in plantations of poplars, particularly when the trees are young (GEORGIEv 1990; Ewald 2003). Records from Salix require confirmation.

Larva and biology: Larva is described by Lorenz \& Kraus (1957) and CavalCaselle (1968). Its biology has been investigated by numerous entomologists, e.g. Vollenhoven (1858), Loiselle (1909), Cavalcasalle (1968), Georgiev (1990), Bloemsma \& Hogenes (1997).

\section{Stauronematus saliciphilus sp. $\mathbf{n}$.}

= Stauronematus compressicornis: LISTON \& SРÄTH, 2005 misidentification.

\section{Description}

Body length: 5.0-5.5 mm.

Colour: black. Labrum pale brown. Pronotum almost completely white or bright yellow (Figs 9, 10). Tegulae of the same colour as pronotum. Legs yellow; apical third of rear tibia and entire rear tarsus infuscate; all coxae yellow except for extreme base. Female abdomen black with at least the 
hypopygium and its immediate surroundings brown, or entirely yellow except for the following fuscous markings; parts of terga 1-2 (3rd very slightly) and 7-8, dorsoapical portion of sawsheath (Figs 11, 12). Male abdomen with subgenital plate and harpes brown. Stigma and venation fuscous except for paler costa and subcosta. Wing membrane slightly darkened.

Head in dorsal view strongly contracted behind eyes in female (Fig. 9) and male (Fig. 10). Malar space as long as diameter of front ocellus. Interantennal area with lateral carinae, converging below; separated from frontal area by a weak ridge. Clypeus subtruncate. POL: OOL: OOCL as 1.0: 0.64-0.66: 0.36-0.48 (female) 1.0: 0.58-0.62: 0.30-0.35 (male). Punctation on head, pronotum and mesonotum weak; these parts strongly shining. Pubescence pale, shorter than diameter of an ocellus. Mesepisternum densely pubescent on upper half, usually abruptly entirely glabrous below this, with a few hairs on extreme lower edge. Without punctures or sculpture. Front mesonotal lobes with medial furrow shallow, obsolete on extreme posterior. Inner hind tibial spur 0.45-0.50 as long as basitarsus. Outer spur $0.55-0.65$ as long as inner. Abdominal terga, except for smooth tergum 1, with weak coriaceous sculpture at $90 \mathrm{X}$ magnification. Terga 1-5 with very sparse pubescence, apical tergites progressively more pubescent. Cerci longer than projecting part of sheath. Sawsheath in dorsal view with longer setae arising at an angle of about $80^{\circ}$ to one another, curved so strongly that their apices are slightly convergent. Lancet of ovipositor (Fig. 13) with 16 annulets. Penisvalve (Figs 14, 15), ventral margin of paravalva emarginate.

Etymology: adjective, meaning having a liking for Salix.

Diagnostic combination: see key and under S. platycerus (above).

\section{Variability:}

One of the Corsican females has the abdominal terga posterior to tergum 2 dark brown, but the Corsican specimens all have a very much darker abdomen than the two females from Sardinia. All the pale body parts in the Sardinian specimens are a more reddish-yellow (orange) than the pale yellow of those from Corsica. Although the glabrous patch on the lower half of the mesepisternum seems to be a useful character for distinguishing the two species, one of the Sardinian S. saliciphilus lacks this, as in most specimens of S. platycerus. The colouration of the Sardinian specimens of $S$. saliciphilus is so strikingly different from those from Corsica, that it seems possible that they might represent a distinct geographical race, but they are considered to be conspecific, because their morphology is very similar. More material and biological information for the Sardinian population should be sought.

Holotype (female): Corsica: Tamaricciu-Tal [Tamaricciu Valley], SW Porto Vecchio, [reared] ex ova an Salix atrocinerea, coll. 11.04.2005, em. 05.2005, leg. J. SрётH (DEI).

Paratypes: Corsica: Tamaricciu-Tal, SW Porto Vecchio, [reared] ex ova an Salix atrocinerea, coll. 11.04.2005, 2 ㅇ $10^{\star}$ em. 05.2005, leg. J. Sрё̈н (DEI, JS); River Figurella near Calvi, $10^{\star}$, 29.04.2004, leg. Liston (DEI). Sardinia, Sta. di Villagrande, $9 \mathrm{~km}$ NW Lanussei, swept from Salix purpurea, 2 ㅇ , 17.04.2006, leg. Liston (DEI).

Hostplant: Salix atrocinerea, possibly also S. purpurea. At the Sardinian locality both these willows occur, but Populus is absent.

Larva and biology (based on observations by J. Sрётн): Feeding habits very similar to those of $S$. platycerus. Eggs are laid on the leaf underside, in the side of the midrib, often in pairs (Fig. 16). Apparently the leaf illustrated in Fig. 16 was laid on twice. Young larvae feed on the edges of holes made in the leaf-blade (Fig. 17), later instars feed on leaf edges. The emergence of 
imagines (Corsican syntypes) shortly after collection of the larvae, indicates that $S$. saliciphilus, like $S$. platycerus, has more than one generation per year.

Distribution: Corsica and Sardinia.

\section{Comments}

In addition to literature records of larvae of S. platycerus (as Lygaeonematus or Stauronematus compressicornis) from various species of Populus, of which $P$. tremula is most frequently mentioned, several previous authors have recorded Salix as a host. The first such mention seems to be by BENSON (1948), repeated in Benson (1958). He does not state the source of his information. Many of the subsequent indications of Salix as a hostplant in the European literature, few of which seem to be based on original data, probably result from BENSON's publications. The only published primary data known to the present author which indicate Salix as the natural host of Stauronematus (under S. compressicornis) are by ОкuтаNi (1967: Salix alopechroa), CaValCaSElle (1968: Salix viminalis) and XIAo et al. (1992: Salix matsudana). Georgiev (1990) wrongly lists Salix alba, misquoting Cavalcaselle (1968) who mentions only Populus alba. Pschorn-Walcher \& Altenhofer (2000) record that larvae of Stauronematus platycerus in Central Europe usually feed on Populus tremula, more rarely $P$. nigra, but were capable of surviving on Salix purpurea in rearing experiments. In the light of the results presented here, the identity of Stauronematus specimens associated in nature with Salix should be checked.

Scobiola-Palade (1981) and Lacourt (1999) state that S. platycerus (as S. compressicornis) has a Holarctic distribution, probably based on Benson (1958). Goulet (1992) mentions the occurrence of Stauronematus in Canada, but this is definitely based on BENSON (1958) (H. Goulet, pers. comm.). Neither H. Goulet nor D. R. SMith (pers. comm.) knows of any definite Nearctic records. Benson (1962), in a review of Holarctic Symphyta, makes no mention of Stauronematus, so at present it seems best to regard his earlier mention of a Holarctic distribution as mistaken.

\section{Records of other species from Corsica and Sardinia}

Hymenoptera Symphyta are generally rather poorly represented on the islands of the Mediterranean, but the numbers of species known from the West Mediterranean islands of Sicily (ca. 100), Sardinia (74), and Corsica (77) greatly exceed those from Crete (28) and Cyprus (34) in the East Mediterranean (TAEGER et al. 2006). The reasons for this are certainly complex, but one of the factors contributing to the difference is likely to be the absence of Salix purpurea and $S$. atrocinerea on Crete and Cyprus. These two willow species contribute significantly to the comparative richness of the Corsosardinian tenthredinid fauna (Liston \& SрÄTH 2005, Liston 2005 and below), supporting seven or eight nematine species which probably do not feed on Salix alba (the only widespread willow species on the East Mediterranean Islands). In total, the combined species list of Symphyta for Corsica and Sardinia includes approximately 120 species. Many of these are recorded from a single or very few specimens. It might therefore be supposed that numerous additional species remain undetected. This is not so in Crete and Cyprus, where relatively many individuals of most species are recorded. Noteworthy in comparison with the fauna of Crete and Cyprus is also the markedly lower proportion of Corsosardinian species with a eumediterranean, or mainly South European distribution. It is not yet possible to state which of the taxa at present known only from Mediterranean islands might represent endemic forms. Particularly with respect to Nematinae, the fauna of mainland Mediterranean countries is still too poorly known. Species are listed below in alphabetical order of the initial letter of the genus name. 
Amauronematus (Brachycoluma) viduatus (ZETTERSTEDT, 1838) (Nematinae)

Sardinia: Sta. di Villagrande, 9 km NW Lanussei, swept from Salix purpurea, 4 9 $10^{\text {七 }}$, 17.04.2006, 1 i $40^{*}, 19.04 .2006$, leg. Liston (DEI).

New for Sardinia. It is not certain that the hostplant of $A$. viduatus at this locality was $S$. purpurea, because $S$. atrocinerea also grew nearby at the same site, although no specimens were collected from the latter.

\section{Craesus alniastri (SCHARFENBERG, 1805) (Nematinae)}

Sardinia: SE Prov. Cagliari, Camisa SE 2.5 km, banks of Rio Piseddu (rushes, Ital. alder, eucalyptus, brambles), 1 ㅇ , 18.-22.07.1998, leg. F. Menzel (DEI).

New for Sardinia.

\section{Chevinia mediterranea LACOURT, 2003 (Blennocampinae)}

Corsica: Tamaricciu-Tal, SW Porto Vecchio, resting on Galium aparine, 1 đ , 21.04.2005, leg. J. Sрётн (JS).

In Corsica previously only known from the type specimens collected in the Fango Valley, NW Corsica, between 09-30.05.1992 (Lacourt 2003).

\section{Euura purpureae KoPELKe, 1996 (Nematinae)}

Corsica: Plain near Corbi [sic, ?= Corti], Bastia \& Ajaccio, Corsica, 1 ㅇ 05.1907 (DEI).

Sardinia: Sta. di Villagrande, 9 km NW Lanussei, swept from Salix purpurea, 2 , , 19.04.2006, leg. Liston (DEI).

New for Corsica and Sardinia. Probably the records by Lacourt (1989) of Euura atra (Jurine, 1807) from Marocco, all from Salix purpurea, really refer to E. purpureae.

\section{Fenella nigrita WESTWOOD, 1839 (Blennocampinae)}

Corsica: near Vignoble Reserve de Président, Etang de J. Diane, E. roadside N198, N. Aleria, 1 , 09.04.2005, leg. J. Sрӓтн (JS).

Leaf-mines of this species on Potentilla reptans were recorded in Corsica by BuHR (1941).

\section{Hoplocampa fulvicornis (PANZER, 1801) (Nematinae)}

Corsica: Outskirts of Ceccia, SW Porto Vecchio, 1 ㅇ , 13.04.2005, leg. J. SрÄтн (JS).

New for Corsica.

\section{Nematinus bilineatus (KLUG, 1819) (Nematinae)}

Corsica: Mountains near Vizzavona, 1 ㅇ , 01.06.1907-30.06.1907 (DEI).

Already recorded by TAEgER et al. (2006) for Corsica, based on this specimen.

\section{Nematus myosotidis (FABRICIUS, 1804) (Nematinae)}

Corsica: Plain near Corbi [sic, ? = Corti], Bastia \& Ajaccio, $10^{\star} 05.1907$ (DEI).

New for Corsica. Head missing, but specimen undoubtedly belongs to this species (as also indicated by an ENSLIN determination label). 
Pontania viminalis (Linnaeus, 1758) (Nematinae)

Sardinia: Gútturu Mannu, 2 km SW Santa Lucia, swept from Salix purpurea, 2 ㅇ $10^{\star}, 18.04 .2006$, leg. Liston (DEI).

New for Sardinia.

\section{Pristiphora luteipes LINDQVIST, 1955 (Nematinae)}

Sardinia: 2 km S Tempio, 1 ㅇ 16.04.2006, leg. Liston (DEI); Sta. di Villagrande, 9 km NW Lanussei, swept from Salix purpurea, 1 , 17.04.2006, leg. Liston (DEI).

New for Sardinia.

\section{Acknowledgements}

I am particularly indebted to Dr. Jochen Späth (Dingolfing, Germany) for the gift or loan of specimens from Corsica and photos of immature stages of $S$. saliciphilus. I heartily thank the following for their help in providing information and material for study: Dr. C. van Achterberg and Dr. R. de Vries (Leiden, Netherlands), Dr. Roy Danielsson (Lund, Sweden), Dr. Henri Goulet (Ottawa, Canada), Mr. K. John Grearson (Ashton Keynes, England), Dr. Jean Lacourt (Igé, France), Dr. Stefan Schmidt (Munich, Germany), Dr. Akihiko Shinohara (Tokyo, Japan), Dr. David R. Smith (Washington, DC), Dr. Veli Vikberg (Turenki, Finland), Dr. Lars Vilhelmsen (Copenhagen, Denmark). Finally, Dr. Andreas Taeger (Müncheberg) made valuable suggestions on the manuscript.

\section{References}

Benson, R. B. 1948: A new British genus of Nematinae related to Pristiphora Latreille (Hymenoptera, Tenthredinidae). - Entomologist's Monthly Magazine, London 84 (9): 22.

Benson, R. B. 1953: Some changes and additions to the list of British sawflies with the descriptions of two new species (Hymenoptera, Tenthredinidae). - Entomologist's Monthly Magazine, London 89 (14): 150-154.

Benson, R. B. 1958: Hymenoptera, Symphyta. - Handbooks for the Identification of British Insects., London 6 (2c): 139-258.

Benson, R. B. 1962: Holarctic sawflies (Hymenoptera: Symphyta). - Bulletin of the British Museum (Naural. History) Entomology Series, London 12 (8): 379-409.

Blank, S. M. \& TAEger, A. 1998: Comments on the taxonomy of Symphyta (Hymenoptera) (Preliminary studies for a catalogue of Symphyta, part 4). - In: TAEger, A. \& Blank, S. M. 1998 (Hrsg.): Pflanzenwespen Deutschlands (Hymenoptera, Symphyta). Kommentierte Bestandsaufnahme. - Goecke \& Evers, Keltern: 141-174.

Bloemsma, B. \& Hogenes, W. 1997: Palissadenbladwespen Stauronematus compressicornis. - Niewsbrief sectie Hymenoptera van de Nederlandse Entomologische Vereniging 5: 25-26.

Butr, H. 1941: Beobachtungen über Nahrungspflanzen, Verbreitung und Auftreten von minierenden Blattwespen. - Mitteilungen der Münchner Entomologischen Gesellschaft, München 31: 903-926.

Cameron, P. 1878: Notes on British Tenthredinidae. - Entomologist's Monthly Magazine, London 14 (168): 265-268.

Cameron, P. 1885: A monograph of the British phytophagous Hymenoptera (Tenthredo, Sirex and Cynips, LINNÉ). - London 2: i-vi, 1-233 \& 27 plates.

Cavalcaselle, B. 1968: Contributo alla conoscenza di Stauronematus compressicornis (F.) (Hymenoptera - Tenthredinidae). - Pubblicazione Centro di Sperimentazione Agricicola et Forestale di Roma, Roma 9: 235-280. 
Costa, A. 1859: Fauna del Regno di Napoli. Imenotteri. Parte III. - Trivellanti Sessiliventri. [Tentredinidei]. - Antonio Cons, Napoli [1859-1860]: 1-116.

Dusmet, J. M. 1949: Revisión de los Tenthredínidos de España. - Memorias de la Real Academia de Ciencas Exactas, Fisicas y Naturales de Madrid, Publicaciones del centenario, Madrid 1 (10): 441-484.

EwaLD, D. 2003: Erste Untersuchungen zur Insektenresistenz transgener Pappeln (First investigations concerning the insect resistance of transgenic poplar clones). - Bundesforschungsanstalt für Forst- und Holzwirtschaft Nachrichten, Hamburg 2003 (3): 4.

FABricius, J. C. 1804: Systema Piezatorum secundum ordines, genera, species adiectis synonymis, locis, observationibus, descriptionibus. - Carolus Reichard, Brunsvigae: 1-30 + 1-440.

Georgiev, G. 1990: Studies of the distribution, bioecology, and control of Stauronematus compressicornis F. in Bulgaria. - Nauka za Gorata, Sofia 27 (2): 72-78.

GhigI, A. 1905: Catalogo dei Tenthredinidi del Museo zoologico di Napoli con osservazioni critiche e sinonimiche. - Annuario dell Museo di Zoologia Napoli, Napoli N. S. 1 [1904] (21): 1-28.

Goulet, H. 1992: The Genera and Subgenera of the Sawflies of Canada and Alaska: Hymenoptera: Symphyta. - In: The Insects and Arachnids of Canada (Part 20). - Agriculture Canada, Ottawa 1876: $1-235$.

Hartig, T. 1840: Hymenopterologische Mittheilungen vom Forstrathe Dr. Th. Hartwig. [sic!]. - Entomologische Zeitung, Stettin 1 (2): 19-28.

Horn, W. (H. R.); Kahle, I.; Friese, G. \& Gaedike, R. 1990: Collectiones entomologicae. Ein Kompendium über den Verbleib entomologischer Sammlungen der Welt bis 1960. Teil 2: L bis Z. -Akademie der Landwirtschaftswissenschaften der DDR, Berlin 2: 221-573.

ICZN 1999: International Code of Zoological Nomenclature. Fourth Edition. - London: 1-306.

KLUG, F. 1819: Die Blattwespen (Tenthredo Linn.) der Fabricischen Sammlung. - Zoologisches Magazin, Kiel 1 [1817-1819] (3): 64-91.

Konow, F. W. 1890: Catalogus Tenthredinidarum Europae. (Hymenopterorum XVI familiae.). - Deutsche entomologische Zeitschrift, Berlin 1890 (2): 241-255.

Lacourt, J. 1989: Sur la présence des genres Euura Newman 1837 et Amauronematus Konow 1890 au Maroc (Hymenoptera, Tenthredinidae). - Nouvelle Revue d' Entomologie (N. S.), Paris 6 (1): 89-92.

LACOURT, J. 1998: Révision des tribus de la sous-famille des Nematinae dans le monde avec création de trois nouveaux genres (Hymenoptera, Tenthredinidae). - Nouvelle Revue d' Entomologie (N. S.), Paris 15 (1): 73-86.

LACOURT, J. 1999: Répertoire des Tenthredinidae ouest-paléarctiques (Hymenoptera, Symphyta). - Mémoires de la Société Entomologique de France, Paris 3: 1-432.

LACOURT, J. 2003: Reflexions sur la classification des Blennocampinae, avec description d'un nouveau genre et d'une nouvelle espece du sud de la France et de Corse (Hymenoptera, Tenthredinidae). - Bulletin de la Société Entomologique de France, Paris 108 (5): 495-529.

Liston, A. D. 2005: The sawfly genus Amauronematus in Corsica, with a new species of the subgenus Brachycoluma (Hymenoptera, Tenthredinidae). - Beiträge zur Entomologie, Keltern 55 (2): 271-277.

Liston, A. D. \& SpÄTH, J. 2005: New data on the sawfly fauna of Corsica with the description of a new species Pontania cyrnea sp. n. (Hymenoptera, Symphyta). - Nachrichtenblatt der bayerischen Entomologen, München 54 (1/2): 2-7.

Loiselle, A. 1909: Notes sur la biologie de quelques Chalastogastra. - Feuille des jeunes Naturalistes, Paris 40: $17-24$.

Lorenz, H. \& Kraus, M. 1957: Die Larvalsystematik der Blattwespen (Tenthredinoidea und Megalodontoidea). - Abhandlungen zur Larvalsystematik der Insekten, Berlin 1: 1-389.

Muche, W. H. 1974: Die Nematinengattungen Pristiphora Latreille, Pachynematus Konow und Nematus Panzer (Hymemoptera, Tenthredinidae). - Deutsche entomologische Zeitschrift, N. F., Berlin 21 (1-3): $1-137$. 
Muche, W. H. 1977: Dritter Beitrag zur Blattwespenfauna der Insel Hiddensee (Hymenoptera, Symphyta). - Faunistische Abhandlungen Staatliches Museum für Tierkunde Dresden, Leipzig 6 (28): 313-314.

ОкuтAnI, T. 1967: Food-plants of Japanese Symphyta (II). - Japanese Journal of Applied Entomology and Zoology, Tokyo 11: 90-99.

Pschorn-Walcher, H. \& Altenhofer, E. 2000: Langjährige Larvenaufsammlungen und Zuchten von Pflanzenwespen (Hymenoptera, Symphyta) in Mitteleuropa. - Linzer biologische Beiträge, Linz 32 (1): 273-327.

Scobiola-Palade, X. G. 1981: Hymenoptera. Symphyta. Tenthredinoidea. Fam. Tenthredinidae - Subfam. Blennocampinae, Nematinae. - In: Fauna Republicii Socialiste Romania. Insecta. - Acad. Rep. Soc. România, Bucuresti 9 (9): 1-328.

Smith, D. R. 1979: Suborder Symphyta. Pp. 3-137. - In: Krombein, K. V.; Hurd, P. D., Jr.; Sмith, D. R. and Burks, B. D. (eds): Catalog of Hymenoptera in America North of Mexico. Volume 1, Symphyta and Apocrita (Parasitica). - Smithsonian Institution Press, Washington D.C. 1: xvi + 1198.

Taeger, A.; Blank, S. M. \& Liston, A. D. 2006: European Sawflies (Hymenoptera: Symphyta) - A Species Checklist for the Countries. - Pp. 399-504. - In: Blank, S. M.; Schmidt, S. \& Taeger, A. (eds): Recent Sawfly Research: Synthesis and Prospects. - 704 pp., 16 pl. - Goecke \& Evers, Keltern.

Thomas, P. L. L. 1987: An annotated catalogue of primary types of Symphyta (Hymenoptera) in the Netherlands. - Zoologische Mededelingen, Leiden 61 (5): 61-78.

Thomson, C. G. 1863: Entomologiska bidrag. - Öfversigt af Kongliga Vetenskaps-Akademiens förhandlingar, Stockholm 19 [1862] (10): 611-639.

Verzhutski, B. N. 1981: Rastitel'njadnye nasekomye v ekosistemach vostotshnoj sibiri. - Nauka, Novosibirsk: $1-303$.

Vollenhoven, S. S. C. van 1858: De inlandsche bladwespen in hare gedaanteverwisselingen en levenswijze beschreven. - Tijdschrift voor Entomologie, S'Gravenhage 1: 171-194; Taf. 9-11.

Wong, H. R. 1969: Reassignment of the ambigua group of Pristiphora to a new genus, Sharliphora (Hymenoptera: Tenthredinidae). - Canadian Entomologist, Ottawa 101 (3): 332-335.

Xiao, G. R.; Huang, X.-Y.; Zhou, S. Z.; Wu, J. \& Zhang, P. 1992: Economic Sawfly Fauna of China. - Tianze Eldonejo, Beijing: 1-221.

Zhelochovtsev, A. N. 1988: Pereponchatokrylye. Shestaya chast. - In: Medvedev, G. C. (ed.): Opredelitel' nasekomykh evropeyskoy chasti SSSR. - Nauka, Leningrad 3 (6): 3-237.

Zimsen, E. 1964: The type material of I. C. Fabricius. - Munksgaard, Copenhagen: 656 pp.

\section{Author's address:}

Andrew D. Liston

Leibniz-Zentrum für Agrarlandschaftsforschung (ZALF) e. V.

Deutsches Entomologisches Institut

Eberswalder Strasse 84

D - 15374 Müncheberg

\section{Subject editor:}

Dr. A. TAEger 




Fig. 1: Stauronematus platycerus (HARTIG). Sawsheath in dorsal view. Scale, $0.1 \mathrm{~mm}$.

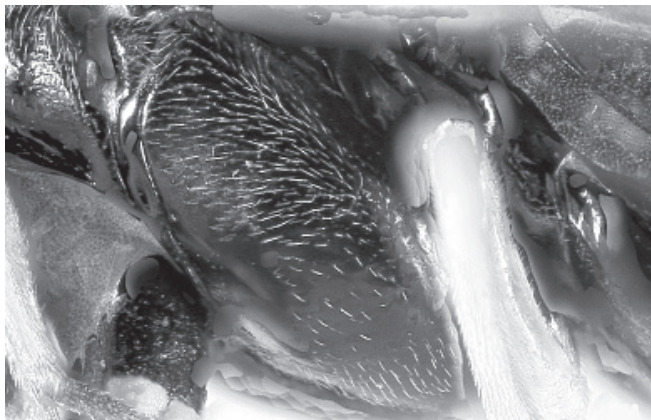

Fig. 3: Stauronematus platycerus (HarTig). Female mesepisternum.



Fig. 2: Stauronematus platycerus (HarTig). Male penisvalve. Scale, $0.1 \mathrm{~mm}$.

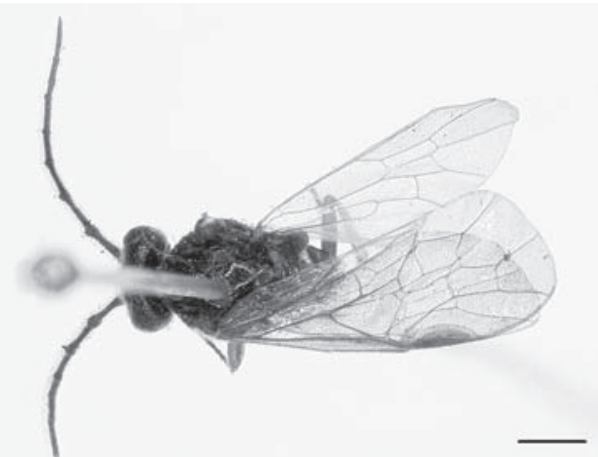

Fig. 4: Cladius (Priophorus) compressicornis (FABRICIUs). Lectotype, male, Tenthredo compressicornis FABRICIUS (dorsa) 1. Scale, $1.0 \mathrm{~mm}$.



Fig. 5: Tenthredo compressicornis FABRICIUs. Lectotype, male (lateral). Scale, $1.0 \mathrm{~mm}$. 


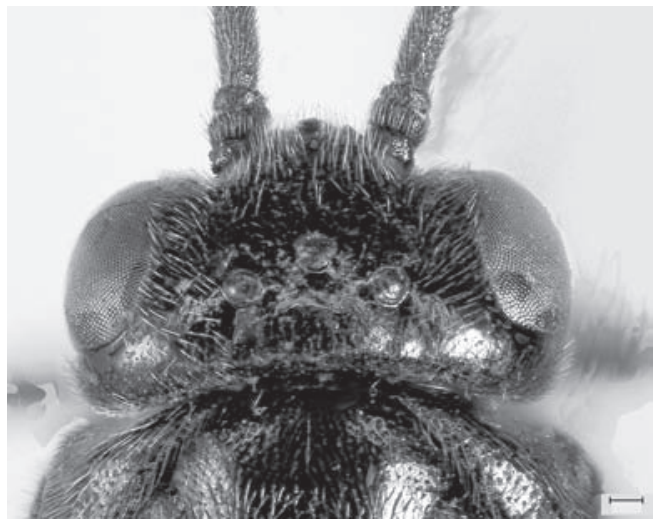

Fig. 6: Stauronematus platycerus (HarTig). Female head and pronotum. Scale, $1.0 \mathrm{~mm}$.

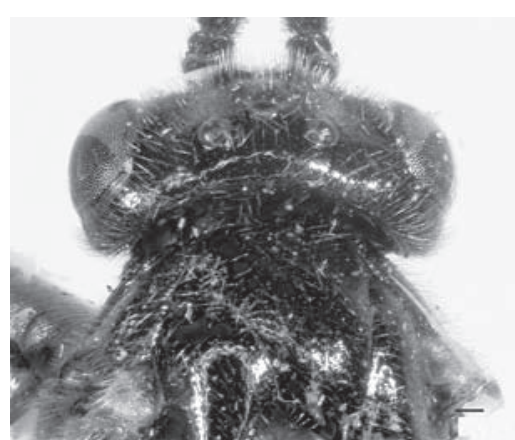

Fig. 7: Stauronematus platycerus (HaRTIG). Male head and pronotum. Scale, $0.1 \mathrm{~mm}$.

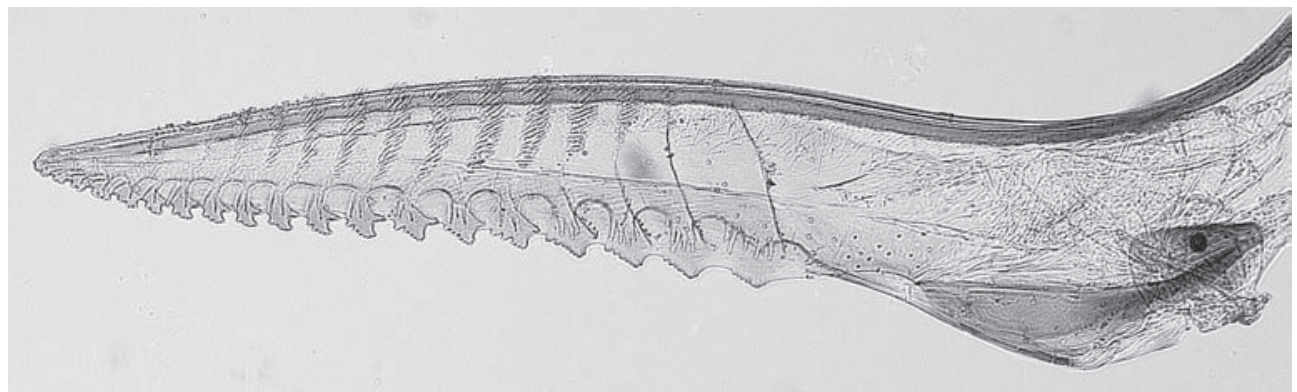

Fig. 8: Stauronematus platycerus (HaRTIG). Female lancet.

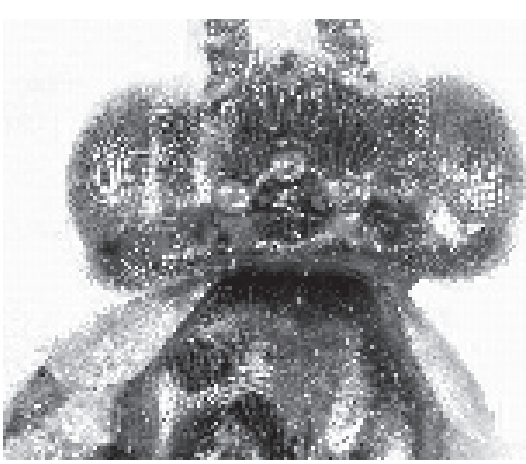

Fig. 9: Stauronematus saliciphilus sp. n. Female head and pronotum. Scale, $0.1 \mathrm{~mm}$.

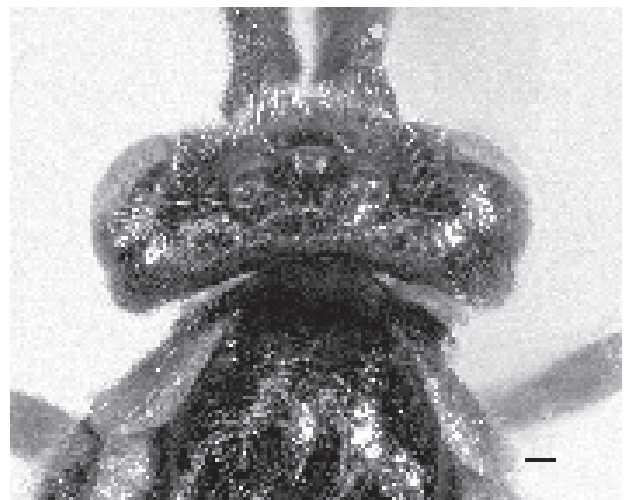

Fig. 10: Stauronematus saliciphilus sp. n. Male head and pronotum. Scale, $0.1 \mathrm{~mm}$. 


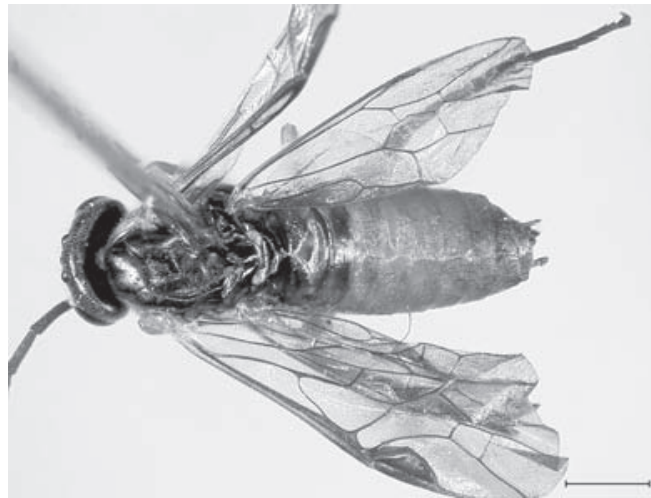

Fig. 11: Stauronematus saliciphilus sp. n. Female (dorsal). Scale, $1.0 \mathrm{~mm}$.

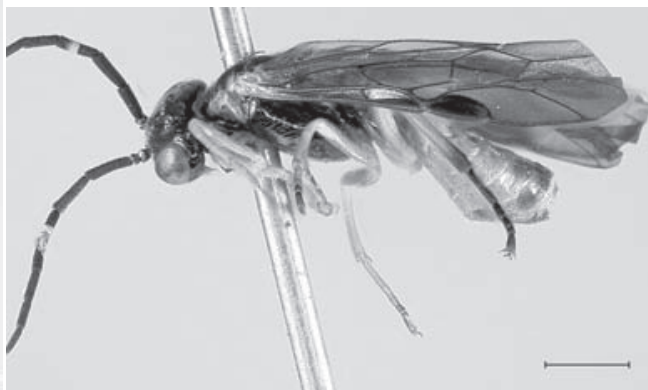

Fig. 12: Stauronematus saliciphilus sp. n. Female (lateral). Scale, $1.0 \mathrm{~mm}$.

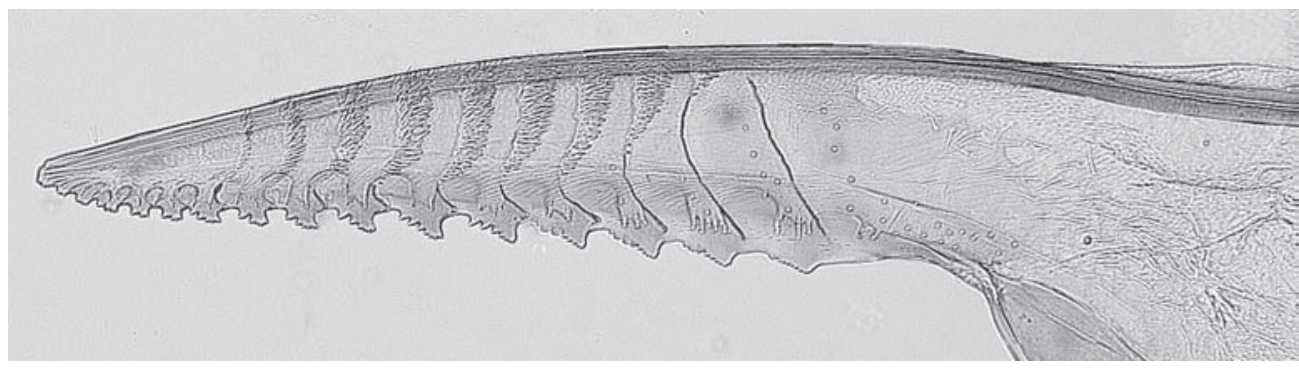

Fig. 13: Stauronematus saliciphilus sp. n. Female lancet.



Fig. 14: Stauronematus saliciphilus sp. n. Male penisvalve. 




Fig. 15: Stauronematus saliciphilus sp. n. Penisvalve (detail).

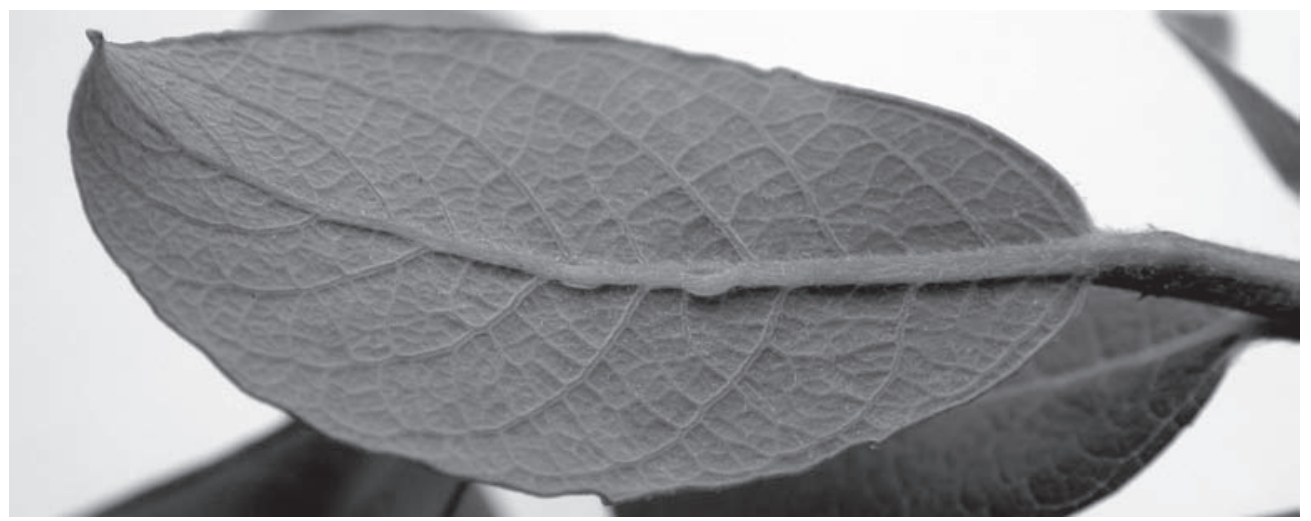

Fig. 16: Stauronematus saliciphilus sp. n. Egg pustules in midrib underside, Salix atrocinerea.

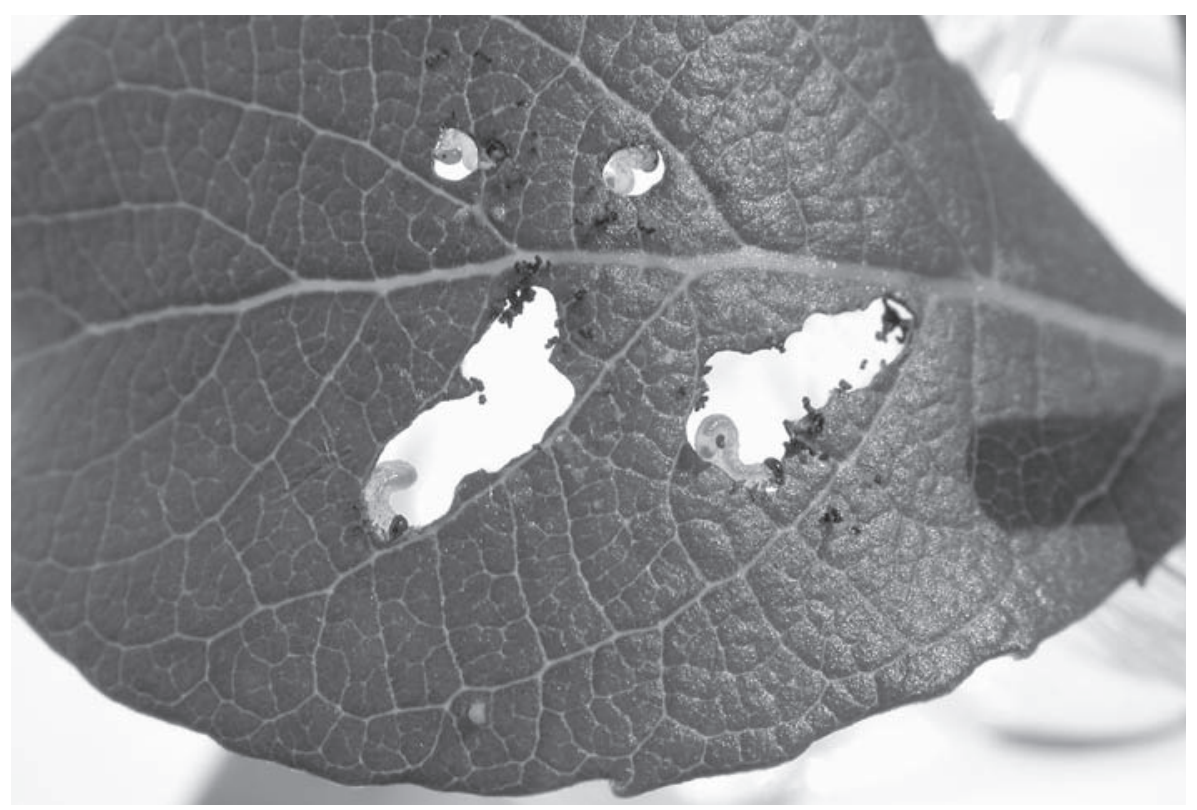

Fig. 17: Stauronematus saliciphilus sp. n. Young larvae on Salix atrocinerea. 